
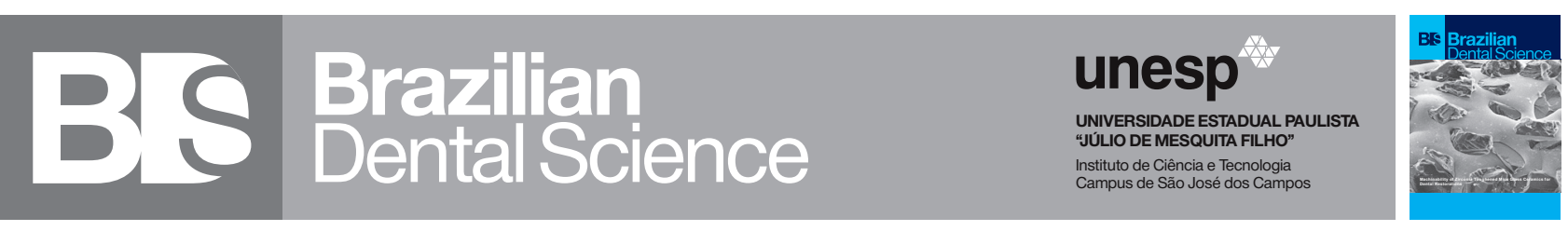

\title{
A CBCT aided assessment for the location of mental foramen and the emergence pattern of mental nerve in different dentition status of the Saudi Arabian population
}

Avaliação auxiliada por CBCT para a localização do forame mentual e o padrão de emergência do nervo mentual em diferentes estados de dentição da população da Arábia Saudita

Kumar Chandan SRIVASTAVA ${ }^{1}$

1 - Department of Oral and Maxillofacial Surgery \& Diagnostic Sciences, College of Dentistry, Jouf University, Sakaka, Saudi Arabia.

\section{ABSTRACT}

Objective: The anatomy of mental foramen (MF) is a noteworthy landmark during any surgical procedures in the inter-foraminal region. Thus, the study aims at evaluating the location of MF and the emergence pattern of $\mathrm{MN}$ in three status of dentition in Saudi Arabian population. Material and Methods: In a prospective study, we have analyzed 240 cone beam computed tomography (CBCT) for the location of MF and the emergence pattern of MN. The study comprising three groups, namely dentulous, partially edentulous and edentulous, each having eighty CBCT scans. We presented the data in percentages. The chisquare and McNemar's test were used for testing association and pair-wise analysis, respectively. Results: The most common location of MF was below the apex of the second premolar irrespective of dentition status, with $54.2 \%$ in right and $60 \%$ in the left side of the jaw. Among the dentition status, left side of the mandible has shown significant variation for the location of MF, whereas gender and age showed variation in the right side. Anterior loop (AL) (Type-III) the emergence pattern of MN was the highest in all dentition status, with $51.7 \%$ in right and $53.8 \%$ on the left side. The variation in the emergence pattern of MN in terms of gender and side of the jaw was statistically significant. Conclusion: In the Saudi Arabian population, the apex of second premolar and type III/AL was the most prevalent location of MF and the emergence pattern of $\mathrm{MN}$, respectively.

\section{KEYWORDS}

Anterior loop; Cone beam CT; Mandible; Mental foramen; Mental nerve.

\section{RESUMO}

Introdução: AObjetivo: A anatomia do forame mentual (FM) é de grande importância durante qualquer procedimento cirúrgico na região inter-foraminal. Por tanto, como objetivo o estudo visa avaliar a localização do FM e o padrão de emergência do NM em três estados de dentição na população da Arábia Saudita. Material e Métodos: Em um estudo prospectivo, analisamos 240 tomografias computadorizadas de feixe cônico (TCFC) para a localização do FM e o padrão de emergência de NM. O estudo compreendeu três grupos, a saber, dentados, parcialmente edêntulos e edêntulos, cada um com oitenta imagens de TCFC. Apresentamos os dados em porcentagens. O teste do Qui-quadrado e o teste de McNemar foram usados para testar associação e análise de pares, respectivamente. Resultados: A localização mais comum do FM foi abaixo do ápice do segundo prémolar independente do estado da dentição, com 54,2\% no lado direito e $60 \%$ no lado esquerdo da mandíbula. Dentre as condições da dentição, o lado esquerdo da mandíbula apresentou variação significativa para a localização dos FM, enquanto o sexo e a idade mostraram variação no lado direito. O padrão de emergência (Tipo III) da alça anterior (AL) do NM foi o mais alto em todos os estados de dentição, com 51,7\% no lado direito e 53,8\% no lado esquerdo. A variação no padrão de emergência de NM em termos de gênero e lado da mandíbula foi estatisticamente significativa. Conclusão: Na população da Arábia Saudita, o ápice do segundo pré-molar e tipo III / AL foi a localização mais prevalente de FM e o padrão de emergência de NM, respectivamente.

\section{PALAVRAS-CHAVE}

Alça anterior; Forame mentual. Mandíbula. Nervo mandibular. Tomografia computadorizada. Tomografia computadorizada de feixe cônico. 


\section{INTRODUCTION}

$\mathrm{T}$ he mental foramen (MF) is an essential anatomical landmark in the mandible through which the terminal branch of the inferior alveolar nerve (IAN), known as mental nerve (MN) and vessels take an exit. Having knowledge about MF's position and the emergence pattern of $\mathrm{MN}$ is of paramount importance in various surgical procedures. The risk of damaging the $\mathrm{MN}$ during various oral surgical procedures, including genioplasty, orthognathic surgery, removal of cyst and tumors and placement of dental implants (DI) are relatively high $[1,2]$. One of the complication of $\mathrm{MN}$ injury can be a paraesthesia because of overfilling of local anesthesia in the close vicinity of MF [3].

The mandible is a constantly growing structure, and they reported that the MF changes its location with age [3]. In elderly individuals because of the atrophic mandible the MF shifts superiorly whereas in children, its position is relatively inferior to the elder age group, towards the lower border of mandible [4]. MF has shown variation in size, location, shape, gender and number [5-15]. Its difference concerning ethnic race is a significant factor and should consider it during the pre-surgical planning phase, and during clinical procedures [12-16].

An essential aspect of MF is how the MN is taking an exit from it. During its exit, it can show a loop formation known as an anterior loop (AL) of the MN. According to solar et al. [17], they have categorized the AL into three types, i.e. type I, type II and type III.

With the limitation of overlapping structures in two-dimensional (2D) radiographic techniques such as intraoral periapical radiograph (IOPA) or orthopantomography (OPG), it cannot identify the exit pattern of MN accurately. Radiographic technique using three-dimensional (3D) technology is beneficial over $2 \mathrm{D}$ radiographic modalities [18-20]. The cone beam computed tomography (CBCT) is a 3D radiographic technique commonly used in various dental surgical procedures to assess normal anatomical landmarks and to identify any pathology.

We should consider an analysis of the factors which can influence the MF via pre-surgical planning on CBCT. Apart from the factors mentioned in the literature, the dentition status can affect the location of MF. Thus, this study aimed at evaluating the position of $\mathrm{MF}$ and the exit pattern of MN in three dentition status in Saudi Arabian population.

\section{MATERIAL AND METHODS}

\section{Description of the Study}

The study followed a prospective, cross-sectional study design during December 2018 to November 2019 at the college of dentistry, the Kingdom of Saudi Arabia (KSA). The study has got the ethical clearance from institutional ethical board (08-09/41). Patients willing to take part in the study had signed the informed consent.

\section{Description of the sample}

We took good quality scans with complete coverage of dental arches for Saudi patients referred for CBCT examination for diagnosis and various treatment needs. The study excluded the patient with attributes such as age below 18 years, coexisting chronic systemic conditions like diabetes mellitus, chronic renal failure, osteoporosis, long-term medication which affects bone metabolism. Additional exclusion criteria includes patient bearing any local or systemic bone pathology, mandibular skeletal deformity, or any local pathologic lesion obscuring the mandibular premolar-molar region. Along with the above criteria, we executed additional exclusion criteria pertaining to the dentition status corresponding to three study groups. Dentulous patients with or without the third molar, included in the first (I) study group. The study adopted the criteria of Kalender et al. [15] for group II partially edentulous patients. In case of missing mandibular premolar or molar, we ensured that the same tooth was present in the opposing arch. The edentulous area in group II and III (edentulous) was no older than 2 years. We calculated the sample size with software-G Power 3.1.9.2 (Heinrich-Heine-Universität Düsseldorf, Germany). Chi square tested at the confidence interval of ( $\alpha$ ).05 with effect size (w) 0.3 in three study groups. A total sample size of 240 achieved with a statistical power of 0.99 . analysis:

Specification of CBCT machine and Image

In the current study, we have used SCANORA ${ }^{\circledR}$ 3Dx CBCT machine (Nahkelantie 160, Tuusula, Finland) for generating scans of the mandibular region of patients. We adopted the specifications of the machine, exposure settings, image acquisition protocol and display software from Sghaireen et al. [21].

We identified the position of MF and the emergence pattern of MN through the MF by using Tebo and Telford classification [22] and solar et al. [17] respectively. In Solar et al. [17] classification, in type-I, AL was not noticeable, and it forms a "Y" shape with no loop. In type-II, AL was absent, and it formed "T" shaped anatomy, whereas the type-III pattern AL was noticeable (Figure $1 \mathrm{~A}-\mathrm{D})$. 

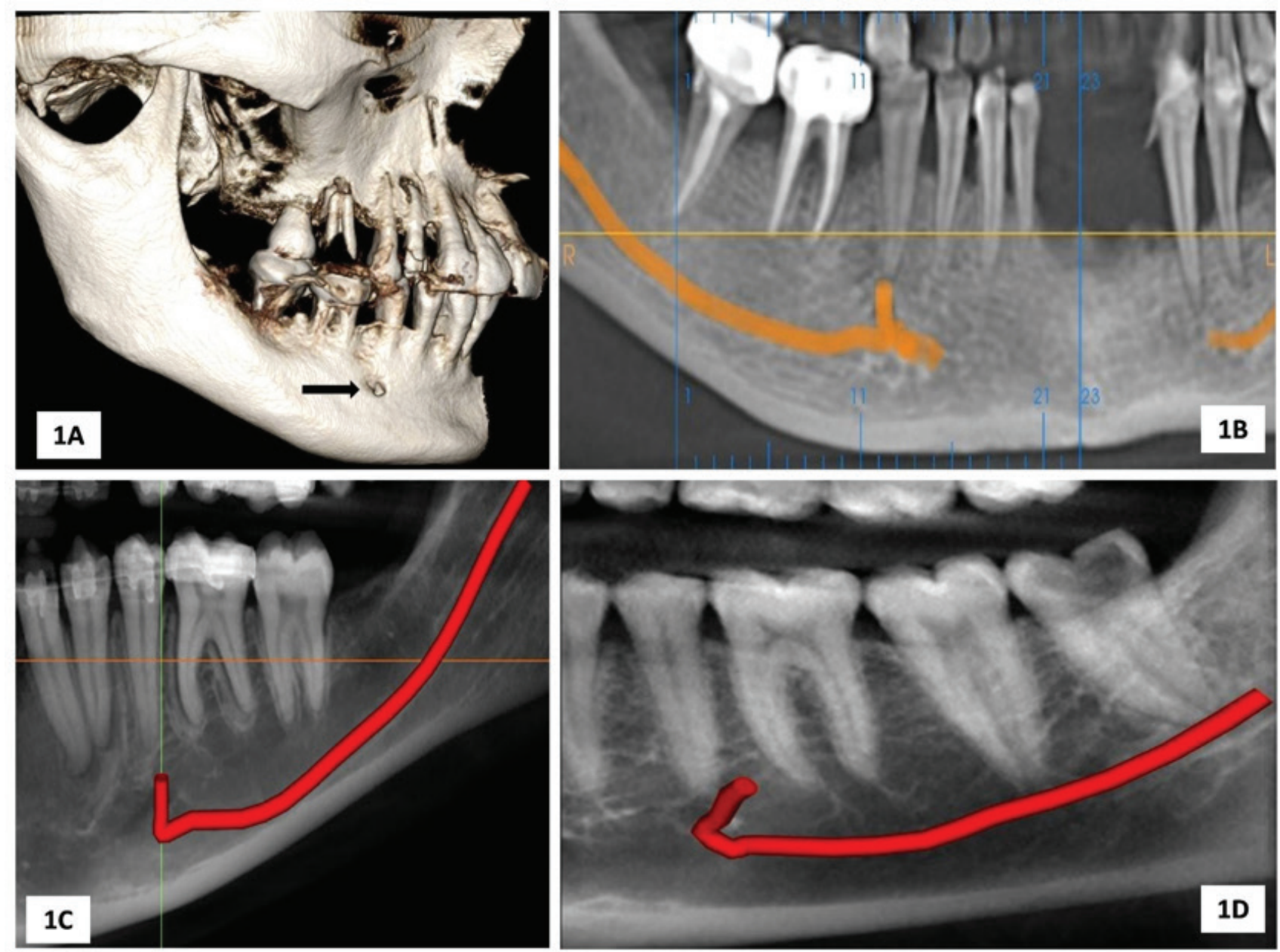

Figure 1 - This is a figure depicting the CBCT scan images showing the various aspects of mental nerve (MN) and its related anatomical structures investigated in the study: (A) Volume rendering image of CBCT is shown with a arrow (black) pointing towards the most common location of the mental foramen (MF) - apex of the 2nd premolar; (B) panoramic reformatted image of CBCT showing the emergence pattern of MN while taking exit from MF - Type I (C) Type II (D) the most common pattern seen in the study - Type III (anterior loop).

We carried all CBCT Image Analysis out by two independent investigators who were professionally certified oral radiologists with over ten years of experience. At the beginning of study, the two examiners underwent a training schedule to standardize the criteria for evaluation. Later, we assessed the interand intra-examiner reliability and found to be 0.93 and 0.94 respectively, thus showing high agreement.

\section{Statistical analysis}

We entered all the data into the MS excel sheet. According to the data, we presented it either in number/percentages or mean with standard deviation. Chi-square tested the association and McNemar analyzed the pair-wise comparison. We performed the data analysis with the Statistical package for social sciences (SPSS) version 21 with $\mathrm{p}<.05$ considered as statistically significant.

\section{RESULTS}

\section{Descriptive statistical analysis}

We analyzed 240 CBCT scans for the current study. Based on the patient's dentition status, we categorized the total scans into three study groups with 80 patients in each group. The dentulous group had a majority $(43.8 \%)$ of 
subjects in $18-25$ years' age group. The group composed of 44 male (55\%) and 36 female (45\%), with a mean age of $38.83 \pm 14.389$ (Standard deviation; Range: 18-60 years). The second group has a male predominance (Male $\mathrm{n}=43 ; 53.8 \%$; Female $-\mathrm{n}=37 ; 46.3 \%)$ with a mean age of $41.54 \pm 12.702$ (Range: $19-60$ ). The edentulous group has all subjects $\geq 54$ Years of age (mean age - $58.41 \pm 2.928$; Range: 54-66) with an equal representation of both gender groups (Table I).

Table I - Descriptive analysis of Sample characteristics

\begin{tabular}{|c|c|c|c|c|c|}
\hline \multirow[b]{2}{*}{ Variable } & \multirow[b]{2}{*}{ Response } & \multicolumn{3}{|c|}{ Study Groups } & \multirow[b]{2}{*}{ Total } \\
\hline & & $\begin{array}{c}\text { Study Group } \\
\text { I-Dentu- } \\
\text { lous } \\
(\mathbf{n}=\mathbf{8 0})\end{array}$ & $\begin{array}{c}\text { Study Group } \\
\text { II-Partially } \\
\text { Edentulous } \\
(n=80)\end{array}$ & $\begin{array}{c}\text { Study } \\
\text { Group III- } \\
\text { Edentulous } \\
(n=80)\end{array}$ & \\
\hline \multicolumn{2}{|c|}{ Age (Mean \pm SD) } & $38.83 \pm 14.389$ & $41.54 \pm 12.702$ & $58.41 \pm 2.928$ & - \\
\hline \multirow{3}{*}{ Age } & $18-35$ Yrs. & $35(43.8)$ & $28(35)$ & - & $63(26.25)$ \\
\hline & $36-53$ Yrs. & $24(30)$ & $28(35)$ & - & $52(21.66)$ \\
\hline & $\geq 54$ Yrs. & $21(26.3)$ & $24(30)$ & $80(100)$ & $\begin{array}{c}125 \\
(52.08)\end{array}$ \\
\hline \multirow{2}{*}{ Gender } & Male & $44(55)$ & $43(53.8)$ & $40(50)$ & $127(52.91)$ \\
\hline & Female & $36(45)$ & $37(46.3)$ & $40(50)$ & $113(47.08)$ \\
\hline
\end{tabular}

Results are expressed as number (\%); SD- Standard Deviation.

\section{Inferential statistical analysis regarding the location of mental foramen}

Determination of the location of MF was the primary aim in the current study. We found the apex of 2nd premolar to be the most prevalent location of MF (Right -54.2\%; Left -60\%), whereas the least reported was at apex of 1st premolar (Right -18.3\%; Left- 9.6\%) (Figure 2). We found this variation significant on the right side of the jaw in relation to gender $(\mathrm{p}=.034)$ and age $(\mathrm{p}=.034)$. However, on the left side, we observed a significant variation with dentition status $(\mathrm{p}=.006)$. While observing the sides within individual dentition status, a significant variation existed in dentulous $(\mathrm{p}=.005)$ and an edentulous group ( $\mathrm{p}=.007)$. Apex of 1 st premolar showed the maximum variation in side-wise comparison, whereas the apex of 2nd premolar showed the highest rate of similarity. Significant $(\mathrm{p}=.004)$ variation existed between the right and left sides irrespective of dentition status (Table II and III).

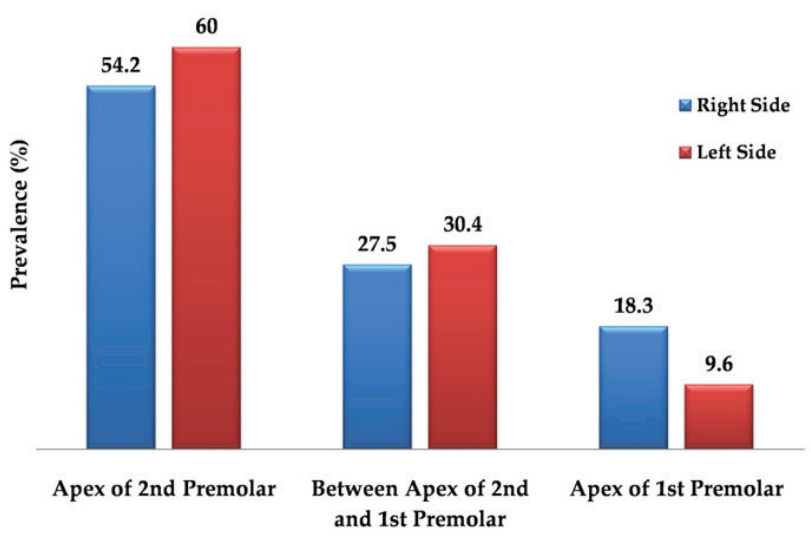

Figure 2 - Locations of mental foramen observed in the current study, with apex of 2nd premolar as the most common irrespective of side of the jaw.

Table II - Comparative analysis of parameters influencing the location of mental foramen

\begin{tabular}{|c|c|c|c|c|c|c|}
\hline \multirow[b]{2}{*}{$\begin{array}{l}\text { Param- } \\
\text { eter }\end{array}$} & \multirow[b]{2}{*}{$\begin{array}{c}\text { Side of } \\
\text { the Man- } \\
\text { dible }\end{array}$} & \multirow[b]{2}{*}{$\begin{array}{l}\text { Dentition } \\
\text { Status }\end{array}$} & \multicolumn{3}{|c|}{$\begin{array}{l}\text { Types of location of } \\
\text { Mental Foramen }\end{array}$} & \multirow[b]{2}{*}{$\begin{array}{c}\mathbf{P} \\
\text { Value }\end{array}$} \\
\hline & & & $\begin{array}{c}\text { Apex of } \\
2^{\text {nd }} \\
\text { Premolar }\end{array}$ & $\begin{array}{l}\text { Between } \\
\text { Apex of } \\
2^{\text {nd }} \text { and } 1^{\text {st }} \\
\text { Premolar }\end{array}$ & $\begin{array}{l}\text { Apex of } \\
1 \text { st } \\
\text { Premo- } \\
\text { lar }\end{array}$ & \\
\hline \multirow{6}{*}{ Dentition } & \multirow{3}{*}{ Right } & Dentulous & $47(58.8)$ & $18(22.5)$ & $15(18.8)$ & \multirow{3}{*}{.121} \\
\hline & & $\begin{array}{c}\text { Partially } \\
\text { Edentulous }\end{array}$ & $49(61.3)$ & $19(23.8)$ & $12(15)$ & \\
\hline & & Edentulous & $34(42.5)$ & $29(36.3)$ & $17(21.3)$ & \\
\hline & \multirow{3}{*}{ Left } & Dentulous & $59(73.8)$ & $18(22.5)$ & $3(3.8)$ & \multirow{3}{*}{$.006^{\star \star}$} \\
\hline & & Edentulous & $46(57.5)$ & $22(27.5)$ & $12(15)$ & \\
\hline & & Edentulous & $39(48.8)$ & $33(41.3)$ & $8(10.0)$ & \\
\hline \multirow{4}{*}{ Gender } & \multirow{2}{*}{ Right } & Male & $71(55.9)$ & $30(23.6)$ & $26(20.5)$ & \multirow{2}{*}{$.034^{\star}$} \\
\hline & & Female & $59(52.2)$ & $36(31.9)$ & $18(15.9)$ & \\
\hline & \multirow{2}{*}{ Left } & Male & $80(63)$ & $36(28.3)$ & $11(8.7)$ & \multirow{2}{*}{.600} \\
\hline & & Female & $46(56.6)$ & $22(32.7)$ & $12(10.6)$ & \\
\hline \multirow{6}{*}{ Age } & & 18-35 & $38(60.3)$ & $10(15.9)$ & $15(23.8)$ & \multirow{3}{*}{$.034^{\star}$} \\
\hline & Right & $36-53$ & $32(61.5)$ & $11(21.2)$ & $9(17.3)$ & \\
\hline & & $\geq 54$ & $60(48)$ & $45(36)$ & $20(16)$ & \\
\hline & \multirow{3}{*}{ Left } & 18-35 & $38(60.3)$ & $18(28.6)$ & 7 (111.1) & \multirow{3}{*}{.133} \\
\hline & & $36-53$ & $38(73.1)$ & $9(17.3)$ & $5(9.6)$ & \\
\hline & & $\geq 54$ & $68(54.4)$ & $46(36.8)$ & $11(8.8)$ & \\
\hline
\end{tabular}

Results are expressed as number (\%), Chi-square test was applied at 95\% confidence interval.

Significant difference at ${ }^{\star} P<.05,{ }^{\star *} P$ value $<.01$. 
Table III - Comparative Analysis of inter-arch pattern of Mental Foramen location

\begin{tabular}{|c|c|c|c|c|c|c|}
\hline \multirow{3}{*}{ Study Group } & \multirow{3}{*}{$\begin{array}{l}\text { Right side of } \\
\text { mandible }\end{array}$} & \multirow{2}{*}{\multicolumn{3}{|c|}{ Left side of mandible }} & \multicolumn{2}{|c|}{ Inter-arch comparison } \\
\hline & & & & & Patient-wise & Overall \\
\hline & & $\begin{array}{l}\text { Apex of } 2^{\text {nd }} \\
\text { Premolar }\end{array}$ & $\begin{array}{l}\text { Between Apex of } 2^{\text {nd }} \text { and } \\
1^{\text {st }} \text { Premolar }\end{array}$ & $\begin{array}{l}\text { Apex of } 1^{\text {st }} \\
\text { Premolar }\end{array}$ & \multicolumn{2}{|c|}{ Pvalue } \\
\hline \multirow{3}{*}{ Dentulous } & Apex of $2^{\text {nd }}$ Premolar & $44(93.6)$ & $3(6.4)$ & 0 & \multirow{3}{*}{$.005^{\star \star}$} & \\
\hline & $\begin{array}{l}\text { Between Apex of } 2^{\text {nd }} \text { and } \\
1_{\text {st Premolar }}\end{array}$ & $6(33.3)$ & $12(66.7)$ & 0 & & $.004^{\star \star}$ \\
\hline & Apex of st $^{\text {st }}$ Premolar & $9(60)$ & $3(20)$ & $3(20)$ & & \\
\hline \multirow{3}{*}{ Partially Edentulous } & Apex of $2^{\text {nd }}$ Premolar & $36(73.5)$ & $8(16.3)$ & $5(10.2)$ & \multirow{3}{*}{.875} & \\
\hline & $\begin{array}{l}\text { Between Apex of } 2^{\text {nd }} \text { and } \\
\text { 1st Premolar }\end{array}$ & $5(26.3)$ & $12(63.2)$ & $2(10.5)$ & & \\
\hline & Apex of pst Premolar & $5(41.7)$ & 2(16.7) & $5(41.7)$ & & \\
\hline \multirow{3}{*}{ Edentulous } & Apex of $2^{\text {nd }}$ Premolar & $24(70.6)$ & $10(29.4)$ & 0 & \multirow{3}{*}{$.007^{\star \star}$} & \\
\hline & $\begin{array}{l}\text { Between Apex of } 2^{\text {nd }} \text { and } \\
\text { 1st Premolar }\end{array}$ & $6(20.7)$ & $23(79.3)$ & 0 & & \\
\hline & Apex of $1^{\text {st }}$ Premolar & $9(52.9)$ & 0 & $8(47.1)$ & & \\
\hline
\end{tabular}

Results are expressed as number (\%); McNemar's test was applied at 95\% confidence interval. Significant difference at ${ }^{\star *} \mathrm{P}$ value $<.01$.

\section{Inferential statistical analysis} regarding the emergence pattern of mental nerve

Evaluation of the emergence pattern of MN was the second objective of the study. We observed that AL (Type III) was the most frequent (Right - 51.7\%; Left -53.8\%) and Type I (Y type) was the least reported (Right-20.8\%; Left-17.5\%) the emergence pattern of $\mathrm{MN}$ (Figure 3).

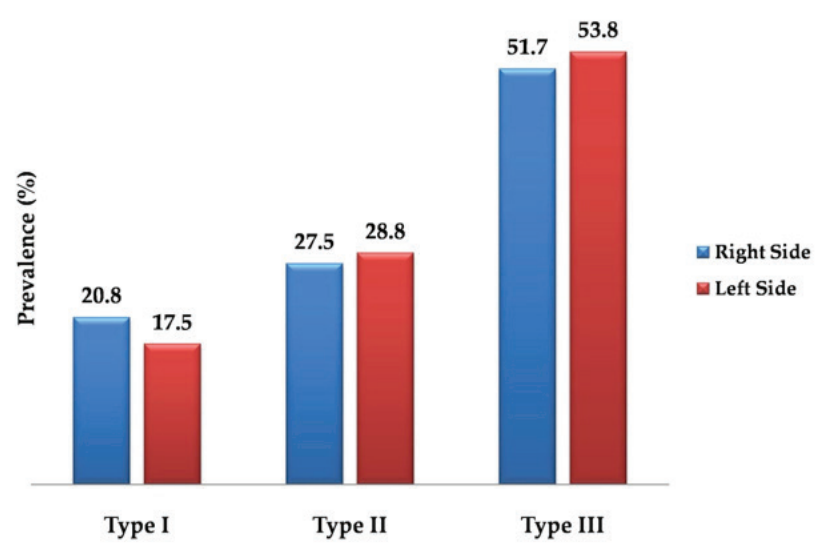

Figure 3 - Emergence pattern of mental nerve observed in the current study, with Type III pattern as the most common irrespective of side of the jaw.
On the right side, the dentition ( $\mathrm{P}=.966)$, gender $(\mathrm{p}=.066)$ and age groups $(\mathrm{P}=.829)$ showed a non-significant variation regarding emergence pattern. Conversely, the left side showed a significant variation among gender ( $\mathrm{p}$ $=.004)$. We observed significant results for the study group I $(\mathrm{p}=.012)$ and II $(\mathrm{p}=.030)$ in comparing their emergence pattern within the dentition groups. The type I pattern reported the highest variation between the sides and type III, the least. A significant variation ( $\mathrm{p}=.025)$ existed between the emergence pattern on the right and left sides irrespective of the dentition status (Table IV and V). 
Table IV - Comparative analysis of parameters influencing the emergence pattern of mental nerve

\begin{tabular}{|c|c|c|c|c|c|c|}
\hline \multirow{2}{*}{ Parameter } & \multirow{2}{*}{ Side of the Mandible } & \multirow{2}{*}{ Left side of mandible } & \multicolumn{3}{|c|}{ Emergence pattern of the mental nerve } & \multirow{2}{*}{ PValue } \\
\hline & & & Type I-Y type & Type II-Ttype & Type III-Loop & \\
\hline \multirow{6}{*}{ Dentition } & \multirow{3}{*}{ Right } & Dentulous & $15(18.8)$ & $24(30)$ & $41(51.3)$ & \multirow{3}{*}{966} \\
\hline & & Partially Edentulous & $18(22.5)$ & $21(26.3)$ & $41(51.3)$ & \\
\hline & & Edentulous & $17(21.3)$ & $21(26.3)$ & $42(52.5)$ & \\
\hline & \multirow{3}{*}{ Left } & Dentulous & $17(21.3)$ & $24(30.0)$ & $39(48.8)$ & \multirow{3}{*}{.717} \\
\hline & & Edentulous & $11(13.8)$ & $24(30)$ & $45(56.3)$ & \\
\hline & & Edentulous & $14(17.5)$ & $21(26.3)$ & $45(56.3)$ & \\
\hline \multirow{4}{*}{ Gender } & \multirow{2}{*}{ Right } & Male & $30(23.6)$ & $27(21.3)$ & $70(55.1)$ & \multirow{2}{*}{.066} \\
\hline & & Female & $20(17.7)$ & $39(34.5)$ & $54(47.8)$ & \\
\hline & \multirow{2}{*}{ Left } & Male & $30(23.6)$ & $27(21.3)$ & $70(55.1)$ & \multirow{2}{*}{$.004^{* *}$} \\
\hline & & Female & $12(10.6)$ & $42(37.2)$ & $59(52.2)$ & \\
\hline \multirow{6}{*}{ Age } & \multirow{3}{*}{ Right } & 18-35 Years & $12(19)$ & $18(28.6)$ & $33(52.4)$ & \multirow{3}{*}{.829} \\
\hline & & 36-53 Years & $12(23.1)$ & $11(21.2)$ & $29(55.8)$ & \\
\hline & & $\geq 54$ Years & $26(20.8)$ & $37(29.6)$ & $62(49.6)$ & \\
\hline & \multirow{3}{*}{ Left } & 18-35 Years & $8(12.7)$ & $21(33.3)$ & $34(54)$ & \multirow{3}{*}{.396} \\
\hline & & $36-53$ Years & $13(25)$ & $11(21.2)$ & $28(53.8)$ & \\
\hline & & $\geq 54$ Years & $21(16.8)$ & $37(29.6)$ & $67(53.6)$ & \\
\hline
\end{tabular}

Results are expressed as number (\%); Chi-square test was applied at 95\% confidence interval. Significant difference at ${ }^{\star} \mathrm{P}<.05,{ }^{* *} \mathrm{P}$ value $<.01$.

Table V - Comparative Analysis of inter-arch pattern of emergence of mental nerve

\begin{tabular}{|c|c|c|c|c|c|c|}
\hline \multirow{3}{*}{ Study Groups } & \multirow{3}{*}{$\begin{array}{l}\text { Right side of } \\
\text { mandible }\end{array}$} & \multirow{2}{*}{\multicolumn{3}{|c|}{ Left side of mandible }} & \multicolumn{2}{|c|}{ Inter-arch comparison } \\
\hline & & & & & Patient-wise & Overall \\
\hline & & Type I-Y type & Type II-Ttype & Type III-Loop & & \\
\hline \multirow{3}{*}{ Dentulous } & Type I-Y type & $12(80)$ & $3(20)$ & 0 & \multirow{3}{*}{$.012^{*}$} & \multirow{9}{*}{$.025^{\star}$} \\
\hline & Type II-T type & 0 & $21(87.5)$ & $3(12.5)$ & & \\
\hline & Type III - Loop & $5(12.2)$ & 0 & $36(87.8)$ & & \\
\hline \multirow{3}{*}{ Partially Edentulous } & Type I-Y type & $11(61.1)$ & $3(16.7)$ & $4(22.2)$ & \multirow{3}{*}{$.030^{\star}$} & \\
\hline & Type II - T type & 0 & $21(100)$ & 0 & & \\
\hline & Type III-Loop & 0 & 0 & $41(100)$ & & \\
\hline \multirow{3}{*}{ Edentulous } & Type I-Y type & $14(82.4)$ & 0 & $3(17.6)$ & \multirow{3}{*}{.083} & \\
\hline & Type II-T type & 0 & $21(100)$ & 0 & & \\
\hline & Type III - Loop & 0 & 0 & $42(100)$ & & \\
\hline
\end{tabular}

Results are expressed as number (\%); McNemar's test was applied at 95\% confidence interval. Significant difference at ${ }^{\star \star} P$ value $<.01$.

\section{DISCUSSION}

Knowledge of MF anatomy in both clinical practice and forensic dentistry is indispensable. The researchers performed studies in the past to locate the MF and the emergence pattern of MN. The technique commonly used to locate was by studying the dissected dry mandible (s) or by using various radiographic techniques, including OPG, computed tomography (CT) and CBCT. In this study, CBCT has been used to identify MF due to its added advantage over OPG. The CBCT produces less distortion and blurred image compared to 2D radiological techniques [23]. Among 3D visualization, CT scans has 1.5-12.3 times more radiation exposure compared to the 
average field of view of a CBCT scan [24]. The study is novel as it gives a complete insight into the location of MF and the emergence pattern of MN in three dentition status among the Saudi Arabian population.

\section{Foramen}

Variation in the position of Mental

The location of MF was by large reported below the apex of mandibular 2nd premolar. We have reported the similar site in our study, irrespective of dentition status. Comparing the location of MF within the Saudi population, our research is consistent with other studies $[14,25]$. Although a study by Shoukry et al. [8] on the Saudi population found the highest prevalence of MF between 1st and 2nd premolar (PM). Ari et al. have reported that the position of the MF is not only dependent on the population but also geographical environment leading to variation within the inhabitant of the same population [26]. The second most common position of MF reported in the present study was between 1st and 2nd mandibular premolar in all the dentition status. Other studies have reported this as a prevalent location in their respective populations $[13,15,27]$. The probable reason for such variation is perhaps because of the ethnicity.

\section{Influence of dentition on location of mental foramen}

The left side showed a significant variation among the dentition status for the location of MF. This is not in agreement with the study carried out by Kalender et al. [15] where there was no significant difference reporter regarding the location of MF on either side of the mandible. Additionally, in this study, MF was prevalent between first and second PM.

\section{Influence of gender on location of mental foramen}

In the present study, we have reported a gender variation on the right side of the mandible regarding position of MF. This resembles to the observations made in a study by Alam et al. where they found in males it was below the second premolar and in females, it was between the premolars [14]. In a study by Khojastepour et al. on the Iranian population, they reported a statistically significant difference in the left side in relation to gender [13]. In another study by Voljevica et al. in Bosnian population, the most common position of MF on the right side was at the long axis of 2nd premolar, whereas it was between 1st and 2nd premolar on the left side [28]. Conversely, Zmyslowska-Polakowska E et al. did not report any gender disparity in relation to the side for the position of MF [5].

Influence of side of mandible on location of mental foramen

When we compared the right and left side position of the MF in dentition status; we reported a statistically significant difference in dentate individuals and edentulous patients. However, the partially edentulous group displayed a non-significant difference. Analysis of the symmetrical position of the MF, on the patient-basis, showed a statistically significant difference, which was consistent with Alam et al. [14]. The fact of being ethnic variation, could attribute it. During prenatal growth, there is a lag in the developmental position, and even it can be because of genetic variation [29]. Contrary to this, there are studies in which it reports a symmetrical pattern of location of MF $[15,30]$.

\section{Influence of age on the location of mental foramen}

Age has an influence on the position of the MF. This observation was obvious in the present study. The MF position on the right side of the mandible displayed a statistically significant difference in distinct age groups. The most common pattern was below the apex of the second PM in 18-35 years age group and the second most common pattern was between the 1st and 2nd premolar except for the age group 18-35 years, where it was below the first molar. This is contrary to the findings of other researchers $[5,15,31]$. 


\section{mental nerve}

Prevalence of the emergence pattern of

An important anatomical landmark which has clinical relevance in implant dentistry as well in oral surgical procedures, including periapical surgeries, is the emergence pattern of MN. The growth of the mandible is a dynamic process which varies with the eruption of the primary tooth. Authors have reported that the MF gets displaced anteriorly till the eruption of a deciduous molar. Later, it develops posteriorly after the second deciduous molar eruption. This could be a probable reason for the development of the $\mathrm{AL}$ of $\mathrm{MN}$ while it emerges through MF [18]. Solar et al.,[17] Kieser et al.,[32] and Demir et al.[33] gave classifications about the emergence pattern of MN.

\section{Influence of dentition on the emergence pattern of mental nerve}

Type-III pattern or formation of AL was the most common pattern observed in all the threedentition status, which was in a range of $48.4 \%$ - 56.3\%. This is contrary to the other Saudi population study where the type-I linear pattern was more prevalent $[19,34]$. Conversely, there are studies done in the varied population where AL pattern (type-III) was more frequent [33, 35, 36]. As per literature, the prevalence of AL of the MN can range from $14.6 \%-90 \%$ [19]. Lorenzo et al. had found variation among the three dentition status wherein they perceived the emergence pattern was in a superior direction in dentate patients and a direct emergence pattern in partially edentulous and edentulous individuals [12].

Influence of side of the mandible on the emergence pattern of mental nerve

In the present study, we reported a statistically significant difference in the right and left side of the mandible concerning emergence pattern in the dentate and the partially edentulous patient. In contrast, the difference was not statistically significant in the edentulous patient. This is contrary to the study done in the Spanish population [12]. In a study by Al-Mahalawy et al., 79.1\% of cases the same pattern observed on the left and right side [34].

Influence of gender on the emergence pattern of mental nerve

Studies have shown that there is gender variation seen in the emergence pattern of $\mathrm{MN}$ [37-39]. In the present study, we also have observed the same pattern on the left side of the mandible which was statistically significant. The most common design was type-III in both the male and female group, but type-II was the second most common in female, whereas type-I was in the male. AL was more common in the male compared to female. Contrary to this, Torres MV et al. reported non-significant variation in the emergence pattern of MN among the gender [40].

\section{Influence of age on the emergence pattern of mental nerve}

Irrespective of the age group, type-III was more prevalent. This observation contradicted another study by Lorenzo et al. [12] where he found that people with less than 50 years had superior emergence and above 50 years had a direct emergence pattern of MN. In another study by Torrens et al., found that AL pattern was inversely proportional to age [40].

Considering the observation in the present study, a variation in the different dentition status as well asymmetrical pattern, age, gender, it is imperative to evaluate pre-surgically the position and emergence of the MN. Literature too supports that mishap can happen because of the nerve injury leading to paraesthesia of the region [2]. Hence, clinicians should give due consideration to the anatomy of this region while doing any surgery, including DI placement.

\section{Limitations and Future direction of the study}

Morphometric analysis with an assessment of accessory mental foramen will provide a holistic picture about the MF anatomy. Multicenter studies will provide a global comparison of the variations existing in MF anatomy. 


\section{CONCLUSIONS}

The present study concludes that irrespective of the dentition status in the Saudi population, the most favourable location of the MF, was at the apex of the second premolar. Along with this, AL formation of MF was the most frequent pattern among all dentition status with no gender or side variation for the type-III pattern.

\section{Acknowledgments}

The author is grateful to Dr. Deepti Shrivastava for her critical review of the manuscript.

\section{Funding}

This is a self-funded study.

\section{Conflict of interest}

The authors have no proprietary, financial, or other personal interest of any nature or kind in any product, service, and/or company that is presented in this article.

\section{Regulatory Statement}

This study was conducted in accordance with all the provisions of the local human subject's oversight committee guidelines and policies of: Jouf University, Kingdom of Saudi Arabia. The approval code for this study is: 0809/41.

\section{REFERENCES}

1. von Arx T, Friedli M, Sendi P,Lozanoff S, Bornstein MM. Location and dimensions of the mental foramen: a radiographic analysis by using conebeam computed tomography. JEndod. 2013;39(12):1522-8.doi: 10.1016/ joen.2013.07.033

2. Weiss R2nd, Read-Fuller A. Cone beam computed tomography in oral and maxillofacial surgery: an evidence-based review. Dent J (Basel).2019 May 2;7(2):52. doi: $10.3390 / \mathrm{dj} 7020052$

3. Goyushov S, Tözüm MD, Tözüm TF.Assessment of morphological and anatomical characteristics of mental foramen using cone beam computed tomography. Surg Radiol Anat. 2018 0ct;40(10):1133-9. doi: 10.1007/s00276018-2043-2

4. Charalampakis A, Kourkoumelis G, Psari C, Antoniou V, Piagkou M, Demesticha T,etal. The position of the mental foramen in dentate and edentulous mandibles: clinical and surgical relevance. Folia Morphologica. 2017;76(4):70914.doi: 10.5603/FM.a2017.0042
5. Zmyslowska-PolakowskaE, Radwanski M,Ledzion S, Leski M,Zmyslowska A Lukomska-SzymanskaM. Evaluation of size and location of a mental foramen in the polish population using cone-beam computed tomography. Biomed Res Int.2019;2019:1659476.doi:10.1155/2019/1659476

6. Wei X, Gu P, Hao Y, Wang J. Detection and characterization of anterior loop, accessory mental foramen, and lateral lingual foramen by using cone beam computed tomography. JProsthet Dent 2020 Sep;124(3):365-71. doi:10.1016/j. prosdent.2019.06.026

7. Wang X, Chen K, Wang S, Tiwari SK, Ye L, Peng L Relationship between the mental foramen, mandibular canal, and the surgical access line of the mandibular posterior teeth: a cone-beam computed tomographic analysis. J Endod. 2017;43(8):1262-6.doi: 10.1016/j.joen.2017.03.043

8. Shokry SM, Alshaib SA, Al Mohaimeed ZZ, Ghanimah F, Altyebe MM, Alenezi MA, etal. Assessment of the inferior alveolar nerve canal course among saudis by cone beam computed tomography (pilot study). J Maxillofac Ora Surg. 2019;18(3):452-8.doi:10.1007/s12663-018-1167-3

9. Sheikhi M, Kheir MK. CBCT Assessment of mental foramen position relative to anatomical landmarks. Int J Dent.2016;2016:5821048. doi: $10.1155 / 2016 / 5821048$

10. Rodriguez-Cardenas YA, Casas-Campana M,Arriola-Guillen LE, Aliaga-Del Castillo A, Ruiz-Mora GA, Guerrero ME. Sexual dimorphism of mental foramen position in peruvian subjects: A cone-beam-computed tomography study. Indian JDentRes. 2020;31(1):103-8. doi:10.4103/ijdr.JJDR_557_18

11. Panjnoush M, Rabiee ZS, Kheirandish Y.Assessment of location and anatomical characteristics of mental foramen, anterior loop and mandibular incisive canal using cone beam computed tomography.J Dent (Tehran). 2016;13(2):126-32

12. Muinelo-Lorenzo J, Fernández-Alonso A, Smyth-ChamosaE, SuárezQuintanilla JA, Varela-Mallou J, Suárez-Cunqueiro MM. Predictive factors of the dimensions and location of mental foramen using cone beam computed tomography.PloS one. 2017;12(8):e0179704.doi:10.1371/journal.pone.0179704

13. Khojastepour L, Mirbeigi S, Mirhadi S, Safaee A. Location of mental foramen in a selected iranian population: ACBCT assessment. Iran Endod J. 2015;10(2):117-21.

14. Alam MK, Alhabib S, Alzarea BK, Irshad M, Faruqi S, Sghaireen MG, et al.3DCBCT morphometric assessment of mental foramen in Arabic population and global comparison: imperative for invasive and non-invasive procedures in mandible. Acta Odontol Scand. 2018;76(2):98-104.doi: 10.1080/00016357.2017.1387813

15. Kalender A, Orhan K, Aksoy U. Evaluation of the mental foramen and accessory mental foramen in Turkish patients using cone-beam computed tomography images reconstructed from a volumetric rendering program. Clin Anat. 2012;25(5):584-92.doi: 10.1002/ca.21277

16. Juodzbalys G, Wang H-L, Sabalys G. Anatomy of mandibular vital structures. Partll:mandibular incisive canal, mental foramen and associated neurovascular bundles in relation with dental implantology. J Oral Maxillofac Res. 2010 Apr 1;1(1):e3. doi: 10.5037/jomr.2010.1103

17. Solar P,Ulm C, Frey G, Matejka M. A Classification of the Intraosseous Paths of the Mental Nerve. Int J Oral Maxillofacl Implants. 1994;9(3):339-44.

18. Shaban B, Khajavi A, Khaki N, Mohiti Y,Mehri T, Kermani H. Assessment of the anterior loop of the inferior alveolar nerve via cone-beam computed tomography.J Korean Assoc Oral Maxillofac Surg. 2017;43(6):395-400.doi: 10.5125/jkaoms.2017.43.6.395

19. Alyami OS, Alotaibi MS, Koppolu P, Alosaimy A, Abdulghani A, Swapna LA, etal. Anterior loop of the mental nerve in Saudi sample in Riyadh, KSA. A cone beam computerized tomography study. Saudi Dent J. 2020.https://doi.org/10.1016/j. sdentj.2020.03.001 
20. Srivastava KC, Shrivastava D, Austin RD. Journey towards the 3D dental imaging-The milestones in the advancement of dental imaging. Int. J. Adv. Res. 2016:4:377-82

21. Sghaireen MG, Srivastava KC, Shrivastava D, Ganji KK, Patil SR, Abuonq A, et al. ACBCT Based Three-dimensional assessment of mandibular posterior region for evaluating the possibility of bypassing the inferior alveolar nerve while placing dental implants. Diagnostics. 2020;10(6):406. doi:10.3390/ diagnostics10060406.

22. Veltri M, Ekestubbe A, Abrahamsson I, Wennstrom JL. Three-Dimensional buccal bone anatomy and aesthetic outcome of single dental implants replacing maxillary incisors. Clin Oral Implants Res. 2016;27(8):956-63.doi: 10.1111/clir.12664.

23. Abdelkarim A. Cone-Beam computed tomography in orthodontics. Dent J (Basel).2019 Sep 2;7(3):89. doi: 10.3390/dj7030089.

24. Ludlow JB, Ivanovic M. Comparative dosimetry of dental CBCT devices and 64-sliceCT for oral and maxillofacial radiology. Oral Surg Oral Med Oral Pathol Oral Radiol Endod. 2008;106(1):106-14. doi:10.1016/j.tripleo.2008.03.018

25. Allison JR, Garlington G. The value of cone beam computed tomography in the management of dentigerous cysts - a review and case report. Dent Update. 2017 Mar;44(3):182-4, 186-8. doi:10.12968/denu.2017.44.3.182

26. Aril,Mustafal,Zubeyde Basar K, Ayberk Kurt M. The localization and anthropometry of mental foramen on late Byzantine mandibles. Collegium antropologicum. 2005;29(1):233-6

27. Chkoura A, EI Wady W. Position of the mental foramen in a Moroccan population: A radiographic study. Imaging Sci Dent. 2013 Jun;43(2):71-5. doi: 10.5624/isd.2013.43.2.71

28. Voljevica A, Talović E, Hasanović A. Morphological and morphometric analysis of the shape, position, number and size of mental foramen on human mandibles. Acta Med Acad. 2015;44(1):31-8. doi:10.5644/ama2006-124.124

29. Ngeow WC, Yuzawati Y. The location of the mental foramen in a selected Malay population.J Oral Sci. 2003 Sep;45(3):171-5. doi:10.2334/josnusd.45.171

30. Apinhasmit W, Chompoopong S, Methathrathip D, Sansuk R, Phetphunphiphat W. Supraorbital Notch/Foramen, infraorbital foramen and mental foramen in Thais: anthropometric measurements and surgical relevance.J Med Assoc Thai. 2006 May;89(5):675-82
31. Dos Santos Oliveira R, Rodrigues Coutinho M, Kühl Panzarella F.Morphometric analysis of the mental foramen using cone-beam computed tomography. Int J Dent. 2018 Mar 26;2018:4571895. doi: 10.1155/2018/4571895

32. Kieser J, Kuzmanovic D, Payne A, Dennison J, Herbison P.Patterns of emergence of the human mental nerve. Arch Oral Biol. 2002 Oct:47(10):743-7. doi: 10.1016/s0003-9969(02)00067-5.

33. Demir A, lzgi E, Pekiner FN. Anterior loop of the mental foramen in a Turkish subpopulation with dentate patients: a cone beam computed tomography study. Clin Exp Health Sci. 2015;5(4):231

34. Al-Mahalawy H, Al-Aithan H, Al-Kari B, Al-Jandan B, Shujaat S. Determination of the position of mental foramen and frequency of anterior loop in Saudi population. A retrospective CBCT study. Saudi Dent J. 2017 Jan;29(1):29-35. doi: 10.1016/j.sdentj.2017.01.001

35. Wong SK, Patil PG. Measuring anterior loop length of the inferior alveolar nerve to estimate safe zone in implant planning: ACBCT study in a Malaysian population. J Prosthet Dent. 2018;120(2):210-3. doi:101016/j. prosdent.2017.10.019

36. Lu Cl, Won J,Al-Ardah A, Santana R, Rice D, Lozada J. Assessment of the anterior loop of the mental nerve using cone beam computerized tomography scan. J Oral Implantol. 2015 Dec;41(6):632-9. doi: 101563/aaid-joi-D-13-00346

37. Chappidi V,Swapna L, Dheeraj V,Nikitha G, Kanakagiri M. Evaluation of morphometric variations in mental foramen and prevalence of anterior loop in South Indian population-A CBCT study. J Indian AcadOral Med and Radiol. 2019;31(2):134. doi:10.4103/jiaomr.jiaomr_219_18

38. Rosa MB, Sotto-Maior BS, Machado Vde C,Francischone CE. Retrospective study of the anterior loop of the inferior alveolar nerve and the incisive canal using cone beam computed tomography. Int J Oral Maxillofac Implants. 2013 Mar-Apr;28(2):388-92. doi: 10.11607/jomi.2648.

39. Sahman H, Sisman Y. Anterior loop of the inferior alveolar canal: a conebeam computerized tomography study of 494 cases. J Oral Implantol. 2016;42(4):333-6. doi: 10.1563/aaid-joi-D-15-00038

40. Velasco-Torres M,Padial-Molina M, Avila-Ortiz G, García-Delgado R, Catena A Galindo-Moreno P.Inferior alveolar nerve trajectory, mental foramen location and incidence of mental nerve anterior loop. Med Oral Patol Oral Cir Bucal. 2017 Sep 1;22(5):e630-e5. doi:10.4317/medoral.21905

\section{Kumar Chandan Srivastava}

(Corresponding address)

Department of Oral and Maxillofacial Surgery \& Diagnostic Sciences, College of Dentistry, Jouf University, Sakaka - Al Jouf Province, Postal Code 72345, Saudi Arabia, 